\title{
NEW URBANISM - A NEW APPROACH TO THE WAY AMERICAN BUILDS
}

Zeljka Pavlovich Howard

Architect and planner, professor at City and Regional Planning Department California Polytechnic State University San Luis Obispo, CA 93407 USA.

E-mail: zhoward@calpoly.edu

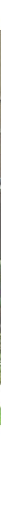




\title{
RESUMO
}

Este artigo apresenta uma visão geral sobre o New Urbanism - um movimento urbanístico com a grande influência no planejamento e na arquitetura americanas. Este advoga um retorno a formas tradicionais do urbanismo e oferece um conjunto de princípios projetuais e urbanísticos para as mais diferentes escalas. O artigo discute algumas das lições apreendidas na última década pela ação desse movimento e os princípios adotados para sua implementação.

Palavras-chave: Novo urbanismo, urbanismo americano, desenvolvimento de comunidades tradicionais.

\begin{abstract}
This article provides an overview of new urbanism, a new influential movement in planning and architecture in the United States that is making a visible impact on the way american towns and cities are built. New urbanism challenges the current development practices in the US which have contributed to urban sprawl, inner city decay, degradation of natural resources, and loss of community identity. It advocates a return to the timeless goals of traditional urbanism and offers a complex set of design principles and public policies to guide development at all scales of the built environment: from the small scale (building, block, street) through the intermediate scale (neighborhood, corridor, district) to the large scale (region, city and town). The article discusses some of the lessons learned from this movement in the last decade, showing why it has gained wide support among professionals, developers, politicians and the general public, and why its principles have been adopted for planning and development of new settlements and redevelopment of existing urban areas.
\end{abstract}

Key words: New urbanism, traditional neighborhood development, transit oriented development, north american urbanism. 


\section{NEW URBANISM \\ A NEW APPROACH TO THE WAY AMERICAN BUILDS}

Radically challenging the way american builds and revitalizes its cities, new urbanism has been characterized as the most important phenomenon to emerge in american architecture and planning since the modernist movement (MUSCHAMP, 1996, 27). New urbanism offers a compelling alternative to the current urban landscape of sprawling developments, and advocates a new approach to structuring public policies and development practices. The result has been a renewed interest in town planning and design as instruments of change.

The basic premise of new urbanism is that the current spatial structure of the american-built environment is dysfunctional and unsustainable - socially, economically and environmentally - and must be reformed to efficiently serve society and preserve the environment. New urbanism advocates reintegration of all components of community life (working, living, shopping and entertainment) into cohesive developments comprised of neighborhoods and cites which are linked with transit and set in a regional framework. The cities and neighborhoods should be diverse, compact, pedestrian oriented, provide alternative modes of transportation, include a mix of uses, and promote social integration. To reach this goal of social, economic, physical, and environmental unity, new urbanism calls for the return to the timeless principles of traditional urbanism and design solutions based on traditional urban forms. These solutions should be adapted to the needs of modern institutions and technology and reflect the local historic heritage and building traditions. The implementation process would be guided by a complex set of design-based principles that operate at all scales of the urban hierarchy - from buildings, blocks and streets, to neighborhoods, districts and corridors; and, ultimately, to cities and metropolitan regions.

The explanation offered by the movement for the complexity of today's dilemma is an assertion that government policies and Euclidean-based development regulations of the last half of the twentieth century have encouraged a sprawling pattern of placeless and disconnected single use suburban developments. Such developments, in turn, have contributed to a myriad of ills: environmental 
degradation, loss of open space, social segregation, irreversible environmental costs, diminished aesthetic qualities, excessive cost of infrastructure and services, inequitable distribution of economic and social resources, and loss of community identity. New urbanists view these problems as "one interrelated community - building challenge" (CONGRESS FOR THE NEW URBANISM, sd).

This challenge, however, could not be resolved within the current regulatory system. The ultimate goal as stated in the Charter of the new urbanism is to "restructure public polices and development practices to support... the restoration of urban centers and towns within coherent metropolitan regions, the reconFiguretion of sprawling suburbs into communities of real neighborhoods and diverse districts, the conservation of natural environments, and the preservation of our built legacy" (CONGRESS FOR THE NEW URBANISM, sd) '.

Like any movement promoting ideas that challenge long standing practices, new urbanism has received its share of criticism. This article focuses on the positive aspects of this movement. It provides an overview of the movement and looks into the lessons that could be learned from the application of its ideas to the design and development of cities.

\section{History of the Movement}

The ideas promoted by new urbanism are not entirely new. Many have been an integral part of the approach to the design and development of western cities for 5,000 years. Intellectual roots of these ideas can be traced back to, among others, Plato and Aristotle and their ideas about the optimum size, layout and design of cites, Camille Sitte's valorization of organic towns, and many twentieth century movements seeking solutions to the problems of modern cities. Among these are the movements inspired by the ideas of John Ruskin and Ebenezer Howard at the beginning of the twentieth century in England, and critical commentaries by Jane Jacobs and Lewis Mumford in the mid twentieth century in the United States. An equally important influence on the formulation of new urbanists ideas can be traced to the contextualism of Rob and Leon Krier and the italian morphologists in the later part of the twentieth century.

Illustrative of many new urbanism ideas are the efforts undertaken in Europe during the last decade of the twentieth century - The New Charter of Athens 1998, adopted by the European Association of Urbanism, and Towards the Urban Renaissance, a study prepared by the British Urban Commission in 1999. Interestingly, the Charter of Machu Pichu, drafted by the International

(1) The Charter of the new urbanism was first publicized by the Congress for the New Urbanism in 1996, and is available for download at www.cnu.org. 
Association of Architects and Urbanists in 1977, was an early on promotion of the principles that are underlying the visions espoused by the charters adopted in the late 1990s by both the american and the european architects and urban planners.

New urbanism first appeared on the scene of american urban planning and architecture in the early 1980s in the ideas espoused by two concurrent movements - Neotraditional Planning and Transit Oriented Development. The two movements were initiated in different parts of the country, but employed similar design principles and shared a common premise and overall goals. Neotraditional Planning started on the Atlantic Coast and was first popularized by the writings and projects of architects Andres Duany and Elizabeth PlaterZyberk of Miami, Florida. Their ideas promoted a return to the principles of traditional urbanism and the design of cities that fosters a sense of community by providing places for all aspects of community life in an aesthetically pleasing spatial structure. Transit-Oriented Development began on the Pacific Coast and was popularized by the works of a Berkeley architect and urban planner, Peter Calthorpe who emphasized a regional approach to urban development that promotes the integration of transit systems on a regional basis. In this regard, Calthorpe advocates the building of compact mixed use development surrounding transit stations.

Followers of these two parallel movements met in 1991 and formulated a set of principles that embodied the essence of their shared ideas. These principles are known as the Ahwahnee Principles, named after the hotel in Yosemite National Park in California where the meeting took place. The widespread acceptance of these principles broadened the support of the two movements, and two years later, in 1993, another meeting was held, this time in Alexandria, Virginia, which led to the creation of a unified movement known today as new urbanism. Members of this movement formed a non-profit organization - The Congress for the New Urbanism (CNU) - and in 1996 adopted a set of principles which are defined in The Charter of the New Urbanism (the Charter).

It is noteworthy to mention that the CNU is often compared to the Congres Internationaux d'Architecture Moderne (CIAM) even though these two organizations have diametrically opposing views on many issues. Both CNU and CIAM focus on similar issues: restructuring the disorder of existing urban environment, improving community life through urban design and linking economic, social, and physical elements into the design of cities. Furthermore, the charters of both organizations contain principles that outline their respective visions of human settlement patterns.

Unlike CIAM, however, which offers a vision of the functional city accommodating cars as an antidote to the chaos of the early part of twentieth century european cities, CNU focuses on neighborhood design and the amelioration of the impacts 
of the automobile on patterns of urban development. The two organizations promoted diametrically opposite ways of accomplishing their respective visions - CIAM advocated a break from history and traditions and mandated a strict separation of uses, while CNU advocates respect for history and return to traditions and believes that cities should provide a diverse mix of uses.

A further distinction between the two organizations is CNU's efforts to use its power as a movement to broaden its base and gain support among all professional organizations that deal with the built environment, including public officials and non-design professions. Collaboration with building professionals - developers, lenders and builders - has proven to be instrumental in much of the success of new urbanism. CNU also seeks cooperation among all interest groups and solicits participation and input from local citizens. CIAM, on the other hand, excluded non-design professionals from its ranks. Both organizations enjoyed a successful relationship with government organizations. However, while CIAM's primary leverage was "top down", derived from large state-sponsored projects, CNU relies on a "bottom-up" approach, and focuses on the impact at the local level through restructuring codes and regulations.

CNU's impact has now also extended into the political arena. Its underlying goals and principles defined by the Charter can be found on the list of state and national programs and political agendas of public figures. For example, the US Department of Housing and Urban Development has adopted the principles of new urbanism as key elements of the federal program known as HOPE VI (Housing Opportunities for People Everywhere) whose purpose is to transform distressed residential areas into mixed-use neighborhoods. The United States General Services Administration, Environmental Protection Agency and the Urban Land Institute have also developed collaborative efforts with the Congress for the new urbanism.

\section{Charter of the New Urbanism}

The Charter outlines a new vision of the spatial and physical form of the contemporary built environment promoted by new urbanism, and defines the principles and development policies which support that vision. The Charter sets out 27 principles to guide planning and design, public policy, and development practices. These principles are organized into three categories, containing nine principles each, that address the three scales of the urban hierarchy. They start at the scale of the region (including the metropolis, cities and towns) followed by the neighborhood (including districts and corridors) and finally the block (including streets and buildings). New urbanists point out that these principles should be considered as a comprehensive sequence dealing with the built environment at every scale. The following is a brief description of the salient points of each set of principles. 


\section{1. The region: Metropolis, city, and town}

The Charter refers to regions as "fundamental economic units of the contemporary world" and calls for coordination of public policies, physical planning, and economic strategies to deal with this new reality. Many issues facing the metropolitan areas, such as equitable use of environmental resources, designation of land for open space and agriculture, transportation and economic development, have regional ramifications and thus cannot be effectively resolved at the local level. Since all elements of the region are interdependent and mutually reinforcing, only a well thought out design of the region can provide parameters for growth in a way that will ensure social, economic, and environmental sustainability of its cities, neighborhoods and districts.

Spatial structure of a region should consist of multiple centers comprised of cities, towns, and villages. Each regional center in turn has its own identifiable center and edge. A regional transportation framework interconnects the centers and minimizes dependence on the automobile by providing pedestrian and bicycle systems and access to transit. Public institutions and services need to be centrally located and be accessible to all residents. Cities and towns within the region should support the regional economy that benefits the diverse population. At the same time, individual cities and towns must provide a wide spectrum of private and public uses that accommodate the residents' needs for work, housing and recreation. Physical geography of the region is defined by the elements of topography, hydrology, open spaces, and farmlands.

All development and redevelopment within the regions must be integrated with the existing urban pattern and should respect local cultural legacy and building traditions.

\section{II.2. Neighborhood, districts and corridors}

The Charter considers neighborhoods, districts and corridors as "the fundamental elements of development". This, the middle scale of the urban hierarchy, best illustrates the key challenges of new urbanism: reaffirmation of the traditional principles of urbanism and the resolution of the conflicts between the traditional urban form and the needs of modern institutions and technology.

The focus is on the neighborhood, which is considered to be "an essential building block" of the social and physical structure of cities. The Charter addresses two types of neighborhoods: 1. Traditional Neighborhood Development (TND) based on Clarence Perry's concept of the neighborhood unit introduced in the First Regional Plan of New York in 1929 and modified here to reflect contemporary institutions, markets and infrastructure needs (Figure 1); and 2. Transit Oriented Development (TOD) as originally formulated by Peter Calthorpe (Figure 2). These two types of neighborhood development have a common premise and share similar characteristics. 

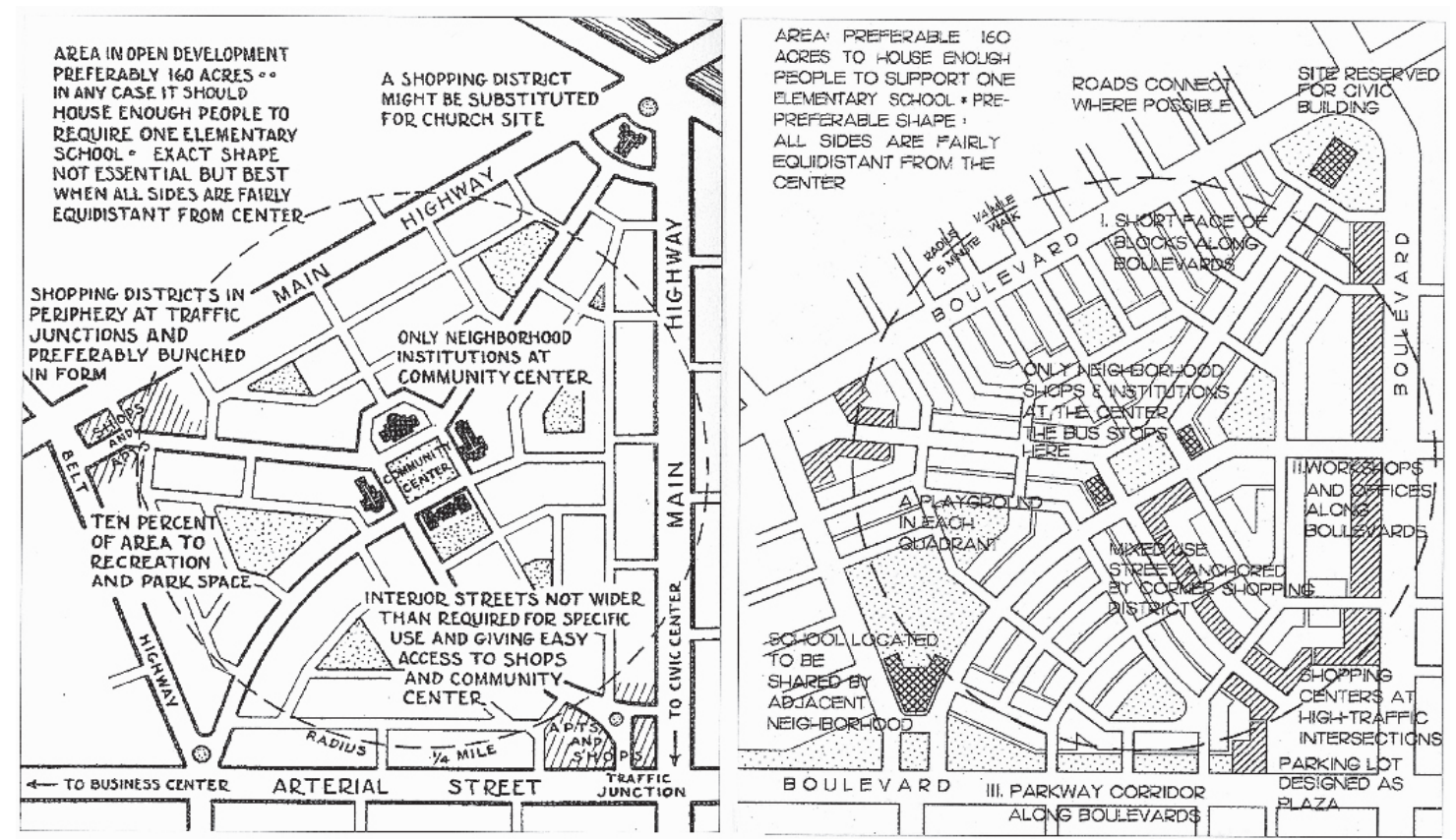

Figura 1: The Neighborhood Unit for the First Regional Plan of New York, a concept by Clarence Perry, 1927; and the Traditional Neighborhood Development concept by Andre Duany, 1997

Source: LECCESE \& MCCORMICK, 1999

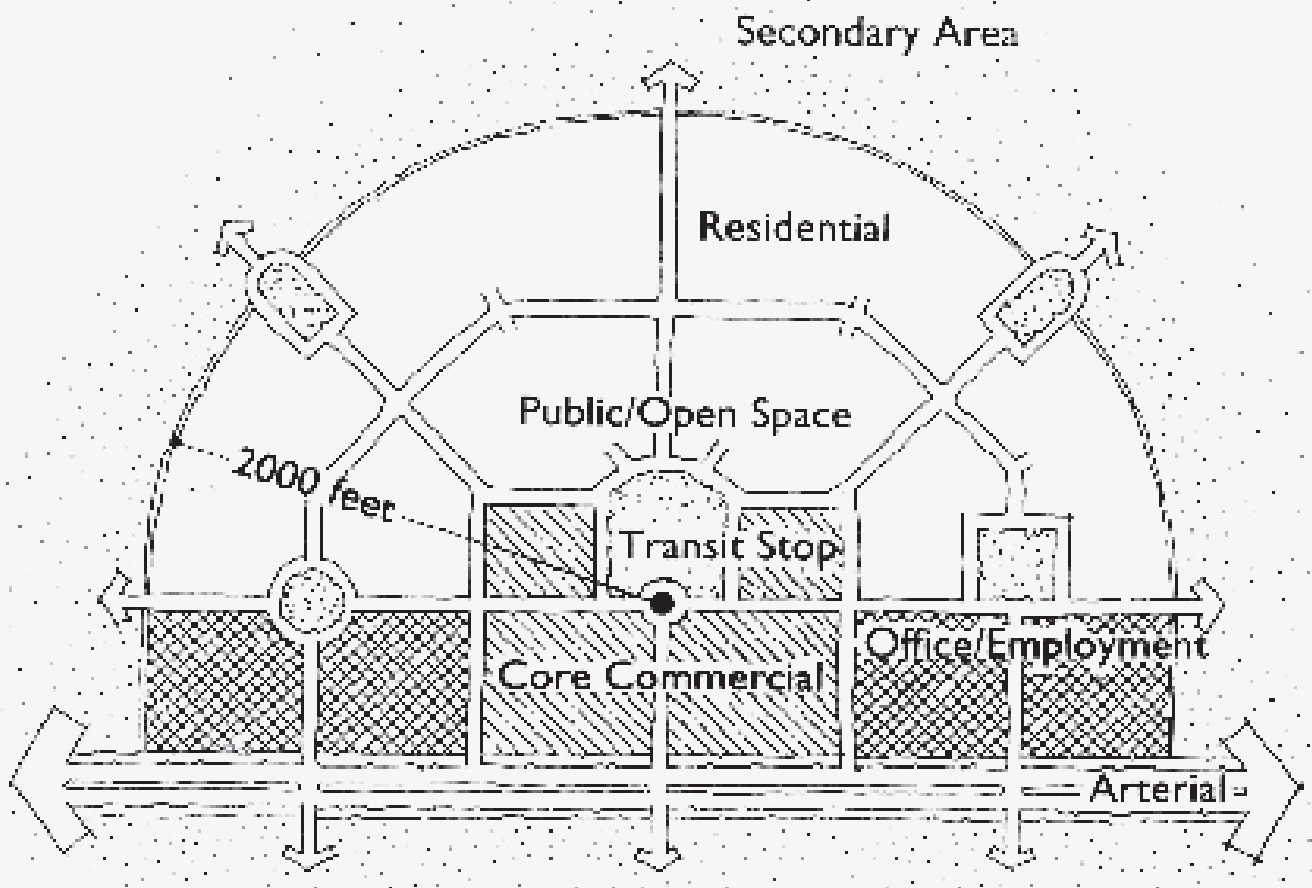

Figura 2: The concept of the Transit Oriented Development, by Peter Calthorpe

Source: CALTHORPE, 1993 
The neighborhood structure should be compact, incorporate mixed-use development, contain a variety of housing types, and be designed to foster social interaction. The optimal size of the neighborhood is defined by a quarter mile distance from the center to the edge, which can be covered in a five to ten minute walk. Within this convenient walking distance is located a mass transit stop (bus or light rail) and all neighborhood activities and services needed to meet the daily needs of its residents. Neighborhood streets are designed to foster pedestrian use, with street trees, wide sidewalks, and street furniture. They also provide for on street parking and accommodate cars and bicycles. Street edges are defined by low to medium high buildings, which are set close together and close to the sidewalks. Open spaces are dispersed throughout the neighborhood.

The focal point of the neighborhood is the center, which contains civic buildings, public gathering places, retail and entertainment establishments. Edges of the neighborhood vary depending on their location relative to the main urban centers. In suburban locations the edges are marked with open spaces; conversely, in dense urban settings, neighborhoods are often bounded with wide streets or boulevards along which are located commercial centers.

Neighborhoods could be created as isolated entities, as parts of infill projects or extensions of a city. The town of Seaside in Florida, designed by Andres Duany and Elizabeth Plater-Zyberk was the first development that employed the neighborhood design principles (Figure 3). A master-planned community designed by Peter Calthorpe, Laguna West, exemplifies the principles of the Transit Oriented Development (Figure 4).

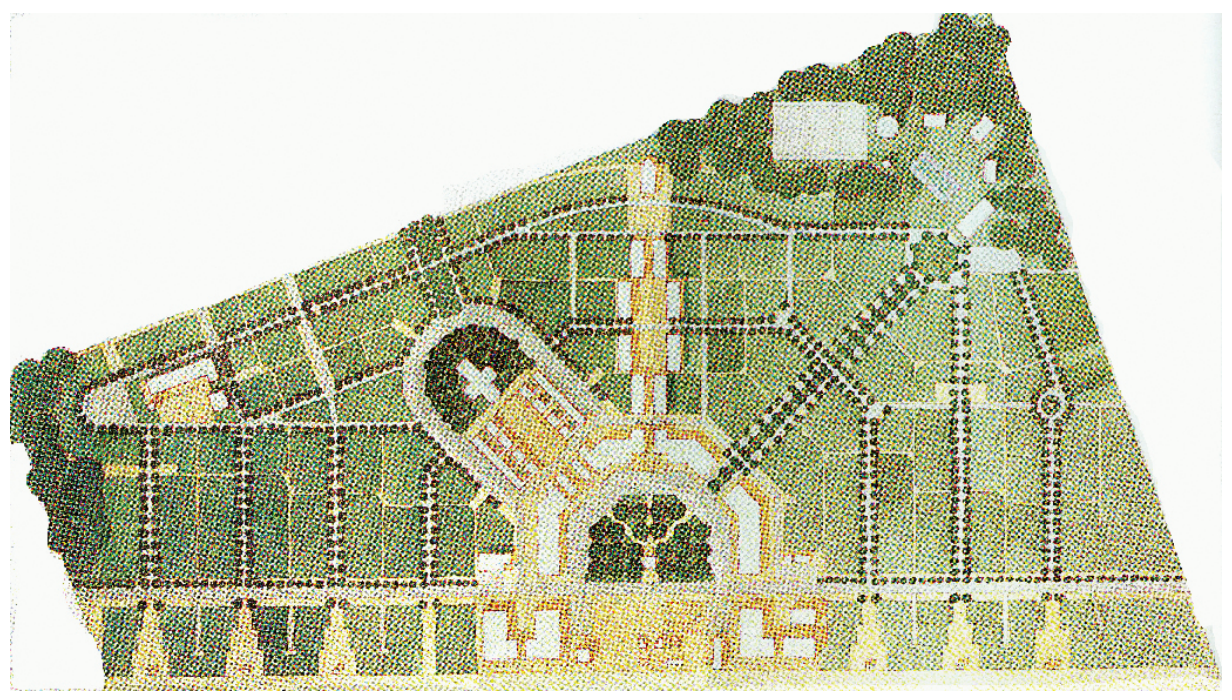

Figura 3: Plan of Seaside, by Duany \& Plater-Zyberk Associates Source: DUTTON, 2000 


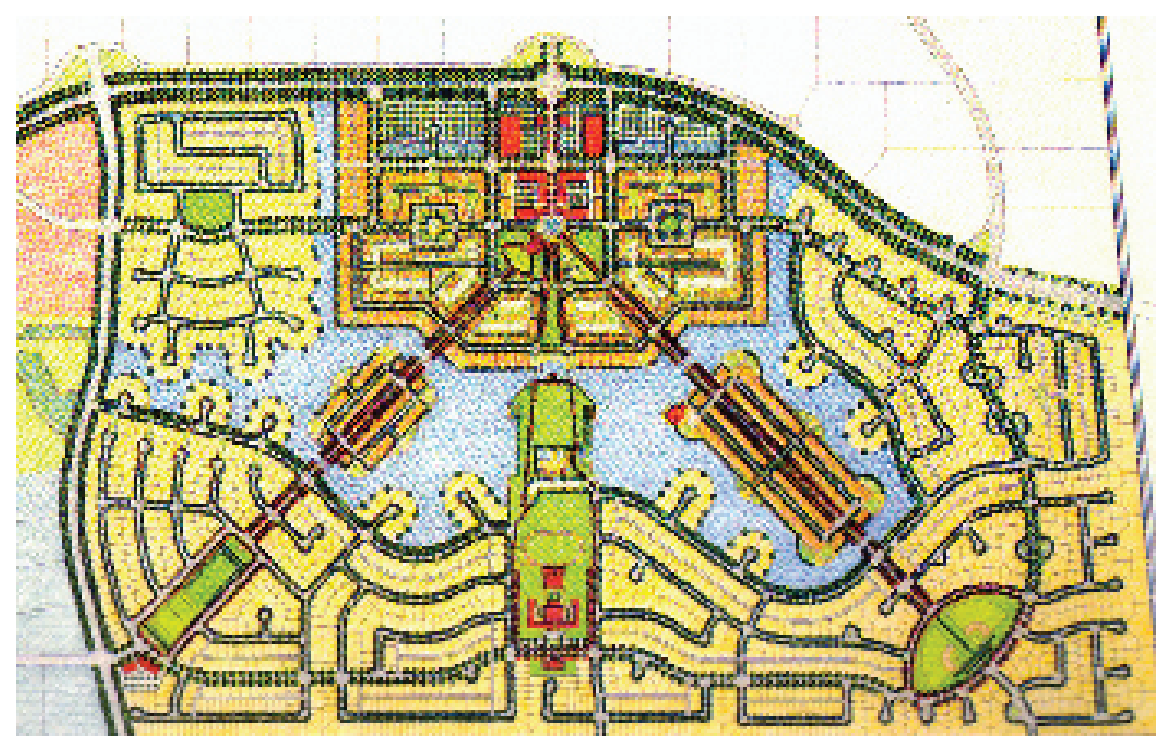

Figure 4: Plan of Laguna West, by Calthorpe and Associates

Source: CALTHORPE, 1993

\section{II.3. Block, street and building}

Blocks, streets and buildings, the smallest scale of the urban hierarchy, are viewed as the essential elements of the traditional urban context. "A primary task of urban architecture," states the Charter, is creating "the physical definitions of streets and public spaces as places and shared uses". Integration of streets and blocks creates a fine-grained structure of public and private spaces. Neighborhoods designed in this way have sufficient flexibility to transform over time, building by building, as needed to accommodate change. Current suburban subdivision designs, by contrast, are not suitable for incremental transformation and can only be changed in their aggregate form.

Design of neighborhood buildings, street layout, and delineation of blocks reflects the local history, environmental characteristics and indigenous building practices. Attention is given to the creation of a unified whole where individual buildings and blocks are not isolated objects but contribute to the definition of public spaces and the creation of a sense of place. Landscape design has also received renewed attention. It is used to span all three scales of development and ties the three together with a system of public spaces including parks, open spaces, promenades, and squares.

\section{Lessons Learned}

\section{1. Integrated approach}

New urbanism brings to fore the importance of an integrated approach to rectifying the problems of urban growth and to bring about change to the 
unsustainable pattern of the current urban landscape. This approach calls for the integration of all factors shaping the built environment-social, economic, ecological and physical. As they are all interrelated, they must be addressed together to reach successful solutions.

The key element in this approach is a regional perspective. The region, new urbanists assert, is a critical factor in the life of all its integral parts - from cities, neighborhoods and districts, to blocks and buildings. Without a consideration of all factors effecting the development of an entire region, even developments designed observing the new urbanism principles could end up being nothing more than a part of faceless urban sprawl.

The application of a regional perspective was first introduced by Patrick Geddes and embraced by Ebenezer Howard at the end of the nineteenth century in England. Daniel Burnham, Lewis Mumford and the Regional Plan Association of America continued this tradition in the United States. However, while planning within the regional context remained an accepted approach to planning in Europe, it received little attention in America with the exception of the plan for Chicago in 1909 and the First New York Regional Plan in 1929.

The works and writings of the CNU members, most notably Peter Calthorpe (CALTHORPE, 1993), brought a renewed attention to the importance of the regional perspective in America in the early 1990s. During the last decade of the twentieth century, the regional perspective has increasingly gained support among planning professionals, politicians, environmentalists and the general public for dealing with problems related to growth, environmental problems, and quality of life. In fact, the support for the regional approach has become strong enough to give impetus to an emerging movement in its own right: "new regionalism".

\section{III.2. Cooperation}

New urbanism asserts that the process for effecting changes in the urban structure and public polices should be based on developing close partnerships and cooperation among various disciplines, interest groups, and citizens. Cooperation is the key element for building support for the change and creating solutions that are responsive to local conditions and wishes of all local stakeholders. A participatory process is now rather common in the United States. Planning laws in many states mandate that citizens be actively involved in many aspects of the planning and decision making process. But, in contrast to many planning efforts where only completed development proposals are presented for public review and comment, new urbanism incorporates public participation throughout the planning and design process. Community involvement plays an important role starting with the discussions about the creation of a common vision, formulation and selection of alternative plans, and ultimately to the creation of implementation strategies. 
The participatory process is usually facilitated by professionals who employ various methods including visioning workshops, visual preference surveys and weeklong urban design charrettes. The use of visual methods - drawings, diagrams, photographs - helps clarify design concepts to laymen who are not familiar with the professional jargon and terminology. Design ideas are communicated in two-dimensional representation of plans and three-dimensional representation of buildings and urban spaces to better facilitate an understanding of how the proposed plans relate to the context of the area. These techniques serve to both educate and engage the public in a meaningful dialogue about the community planning and design issues and help them visualize and evaluate alternative proposals.

\section{III.3. Reaffirmation of the traditional urbanism}

New urbanism has reminded american planners, public officials, and the community, that design matters. Innovative design concepts and visionary proposals are needed to reflect the needs of contemporary life, and they should be integrated across the regional, city, neighborhood, and site scales of development. The movement also stresses the value of traditional principles of urbanism that have guided design of cities for centuries and have created many unforgettable monuments of our urban heritage. The Charter calls for a "return to our obligation to carry on the traditions of the tested craft of traditional urbanism" (CONGRESS FOR THE NEW URBANISM, sd).

An ideal structure of cities and neighborhoods, as described in the Charter, is achieved through the planning and design process that recognizes the need to accommodate multiple sets of activities in a physical setting with a human scale, and at the same time provides opportunities for efficient functioning of modern institutions and the corresponding infrastructure systems. This view is reflected in the principles indicating how all elements of the city must be developed - from the relationship between the individual buildings and the street to the way in which local land uses and densities relate to the regional system of mass transportation. These planning and design principles are applicable in the reconstruction of the existing urban areas, renovation and development of new urban centers, development on the urban fringe, and design of new master planned communities and new towns.

Not surprisingly, new urbanism has been criticized for the attention it gives to the physical design which has rekindled the long-standing debate over the relationship between the built environment and human behavior. Design alone can't make community life flourish, critics say, but as past experiences have showed us, neither can the policies downplaying design. These policies produced some of the most telling examples of development that failed both esthetically and socially, in the inner cities as well as in fringe developments. 
In fact, most of the american post W.W.II "faceless" and "any place USA" development is a testimony to the inadequacy of these policies. New urbanism recognizes the limitations of one-sided development policies, and clearly relates design of places to social, economic and environmental aspects of urban life. The preamble of the Charter clarifies the new urbanists' stand on this point: "Physical solutions by themselves will not solve social and economic problems, but neither can economic vitality, community stability, and environmental health be sustained without a coherent and supportive physical framework."

\section{III.4. Integration of planning, design and implementation}

New urbanism emphasizes the importance of a coordinated approach to planning and development that integrates planning, design and implementation. Many urban problems, claim new urbanists, relate to the absence of coordination between planning at different scales of development and a lack of a clear relationship between planning goals and development policies. The conventional zoning currently widely used as the basic regulatory framework in America is not promoting good planning. On the contrary, it regulates out sustainable development and encourages the separation and dispersal of development. Further, the proliferation of conventional Euclidean-based codes for guiding development creates serious barriers to implementing alternatives to the current development patterns.

New urbanism offers various alternatives to the conventional mechanisms of the regulatory system. Many new codes and regulations were developed to guide planning and project development. These codes translate the goals of the master plans into specific guidelines for planners, developers and architects. Unlike traditional zoning, these guidelines indicate building typologies appropriate for various locations within the neighborhoods and districts, and call particular attention to the design and location of civic buildings as well as buildings and structures defining public places. These guidelines are typically presented graphically in a series of diagrams that are very easy to understand. This is yet another departure form the conventional regulations which are often presented in thick volumes and require legal experts for clarification.

A very powerful alternative approach to the conventional regulations offered by new urbanists is the concept known as "transect" planning. The transect approach provides a new way of classifying development and open spaces which is based on the spatial distribution of urban elements along a geographic cross-section of a region. Its underlying principles are based on ecological theory, which view rural and urban conditions as interconnected parts of a system requiring different forms depending on where development is located.

Transect methodology involves making a horizontal cut through a landscape from the rural setting, where land has the lowest intensity of use and extending 
it on a continuum into the urban core with the highest level of development. In this way, the transect defines a sequence of environments that reflect a range of varying levels of development intensity and provides a comprehensive framework for defining interrelationships between all scales of the rural to urban continuum. Using this framework and the characteristics of geographical settings along the continuum (rural, suburban and urban), appropriate development intensities can be defined for each transect zone. Development in each zone would be guided by a set of planning and development policies that specify types of development plans appropriate for each zone, development intensities and urban morphology, including the types of streets, buildings, and public spaces.

The advantage of the transect approach, believe new urbanists, is in promoting the creation of sustainable urban patterns with urban forms that are interconnected with the rural areas and the other parts of the city. This also leads to a better integration of local and regional building traditions. Equally importantly, transect planning integrates procedures for plan preparation with design and development policies. This is another important advantage of this approach: planning and design goals are reflected in the devices for implementation, which is absent from the current development policies. A model transect code - the Smart Code - was recently developed by Duany Plater-Zyberk \& Associates (DUANY \& TALLY, 2002) and has been implemented in several places in the United States (Figure 5).

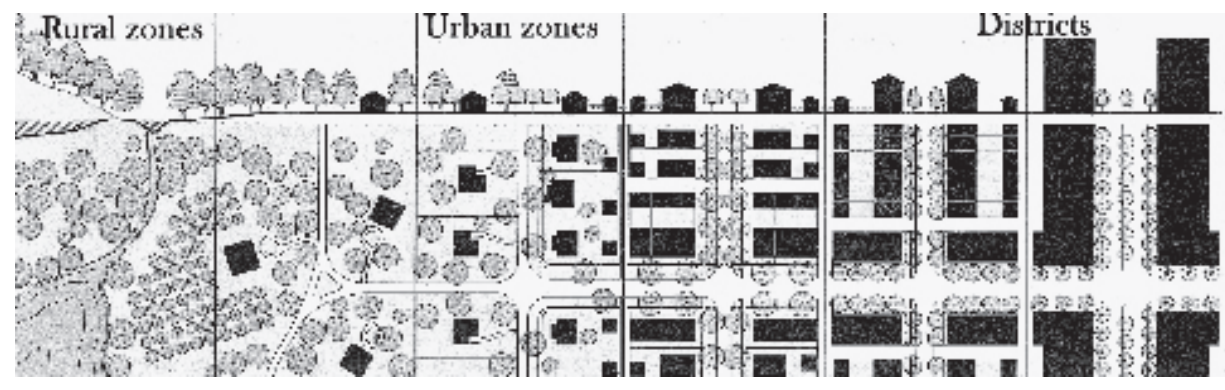

Figures 5a and 5b: Rural to Urban Transect concept by Andre Duany; figure 5b: illustrated by this project by Leo Krier for Luxemburg

Sources: Andre Duany's personal files; drawing courtesy of L. Krier, coloring by Duany Plater-Zyberg \& Co.

\section{Conclusion}

New urbanism, of course, does not offer solutions to all ills of the american built environment. For example, it does not contemplate the programs for economic development, nor the programs for affordable health and social services, nor does it have the power to override market forces and insure housing supply that meets the needs of a diverse population. New urbanism simply offers an alternative approach to developing solutions to the growing challenges of contemporary cities with clearly defined planning policies, design principles, and implementation strategies. 


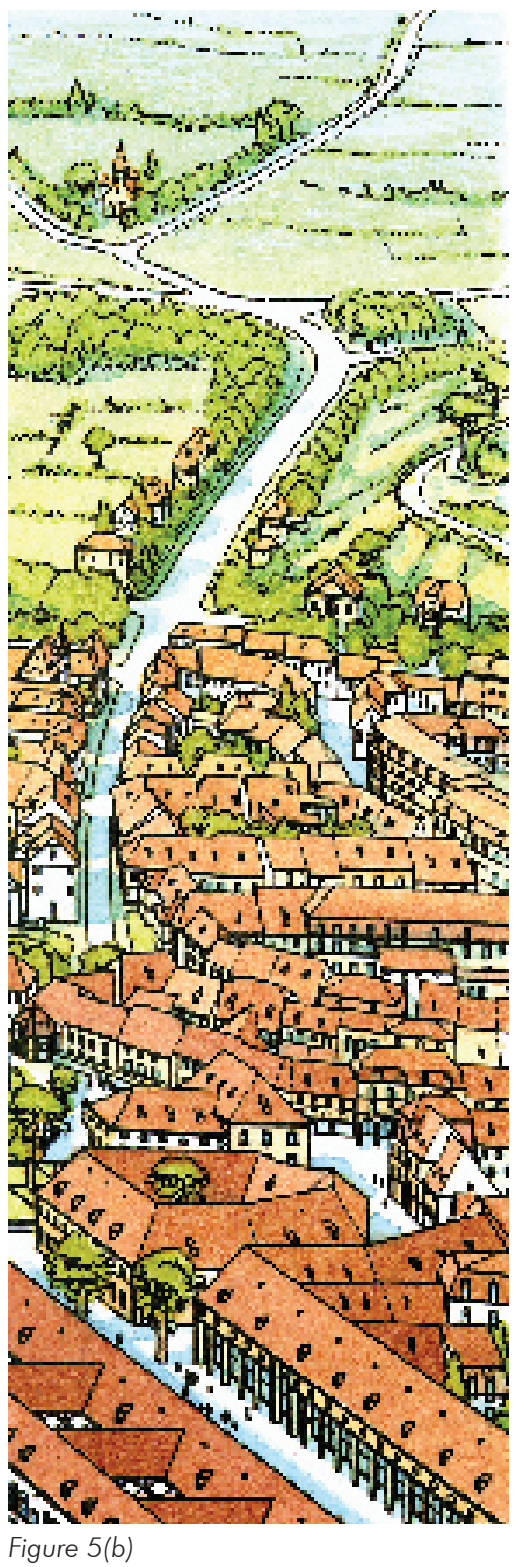

New urbanism now enjoys wide support in the ranks of architects, urban planners, educational institutions, academics, politicians, developers, and the general public, and has inspired significant changes in the approaches to planning and development. Regional and city plans, and development policies in many parts of the country, are undergoing change and including the principles of new urbanism into their development codes. Also, the key principles of new urbanism are now incorporated in the principles and policies of other movements interested in finding solutions to the effect of sprawl and improving the quality of the natural and built environment. They include Smart Growth, Livable Communities and national environmental organizations. The impact of new urbanism has extended into the political arena as well - its underlying goals and principles can be found on the list of state and national programs and political agendas of public figures.

Probably the best testimony to the importance of this movement are the numerous projects whose planning and design are guided by the principles of new urbanism. In 1999, Time Magazine recognized the existence of more than 150 new urbanists developments in the United States and other countries including Philippines, Australia and Finland, while 200 such projects were on the drawing boards (TIME, August 16, 1999). They include the redevelopment of high density residential projects in large cities, revitalization of commercial centers in existing urban areas (grayfields), development of urban areas and urban fringes which were contaminated (brownfields), new master planned communities and new towns outside of existing urban areas (greenfields), and affordable housing developments.

In the last decade many new urbanists projects have been developed that exemplify the principles promoted by the Charter, and that demonstrate there is a significant market "niche" for this kind of development. Among them, Laguna West and The Crossings, both in California and designed by Peter Calthorpe and Associates, are good examples. Laguna West just outside Sacramento in 
a former "greenfield" represents well the large scale new urbanist community with a total of 800 acres and an estimated total population of 9,000 (it has 6,000 in 2003) (Figure 6). The Crossings in Mountain View is a mixed-use compact development built in a "grayfield" (an area previously occupied by a bankrupt shopping center); it now holds a variety of building types and is served by a light-rail station (Figure 7). Many counties and cities are also incorporating new urbanist ideals and guidance into their development codes and guidelines. This is the case, for instance, of Chula Vista county next to San Diego, where the Ottay Ranch - an area with close to 23,000 acres and a projected population of 67,000 - is being developed into a dozen of different "villages" which follow specific plans and urban design guidelines inspired by new urbanism (Figure 8).

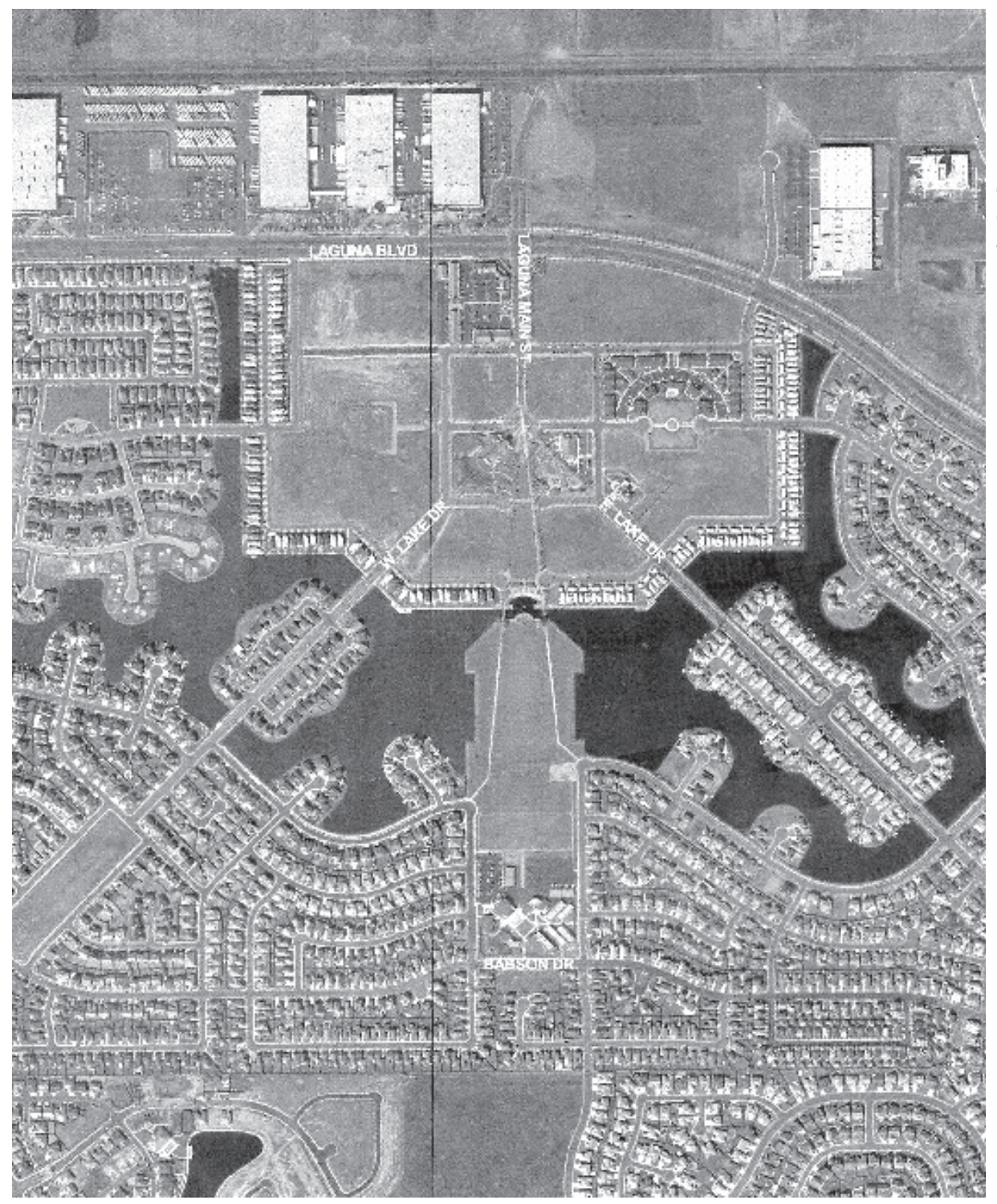

Fig. 6: Aerial photo of Laguna West, as built Source: City of Lakeside website 


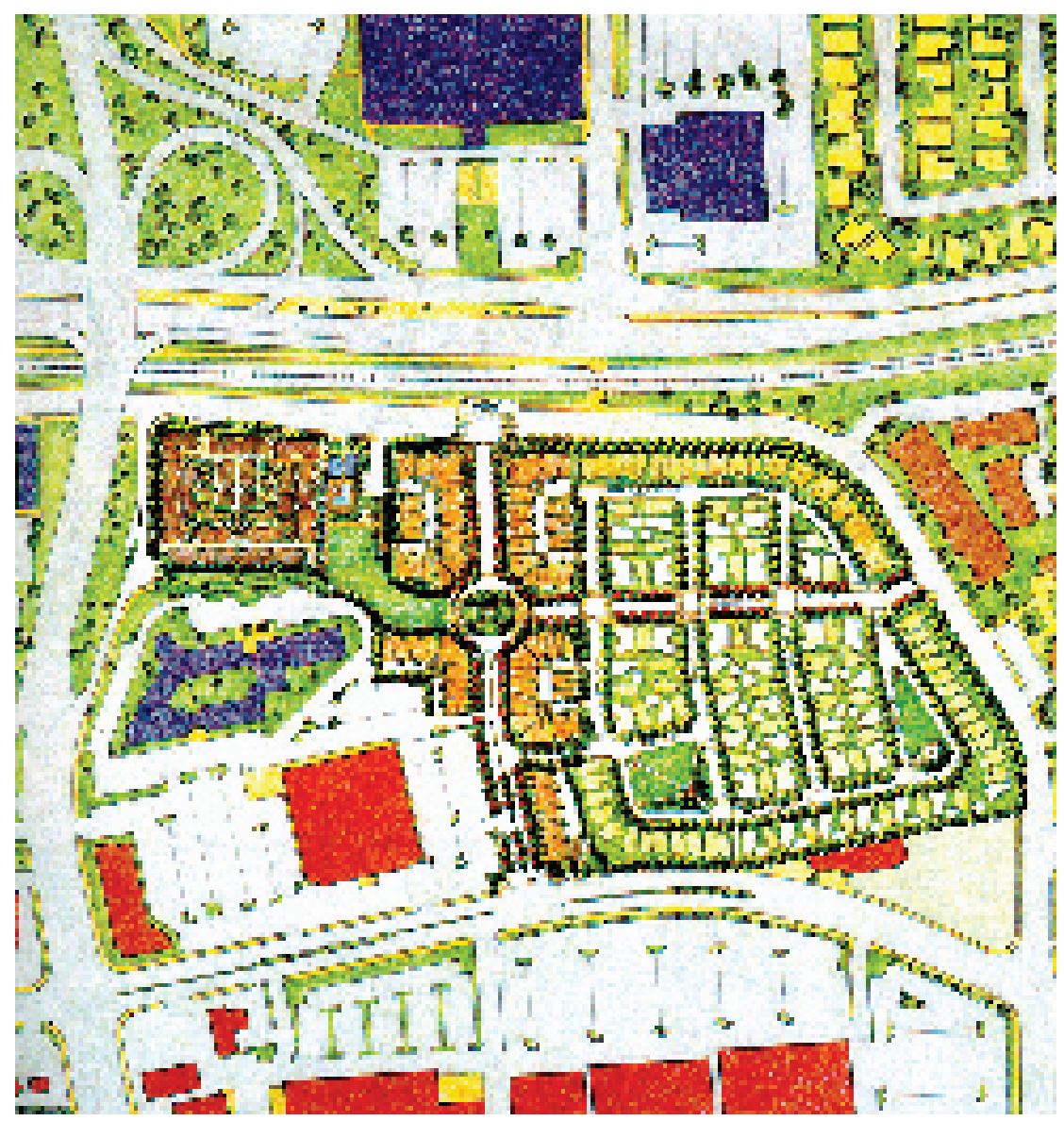

Fig. 8: Apartment housing in Ottay Ranch photo by V. del Rio photo by V. del Rio
photo

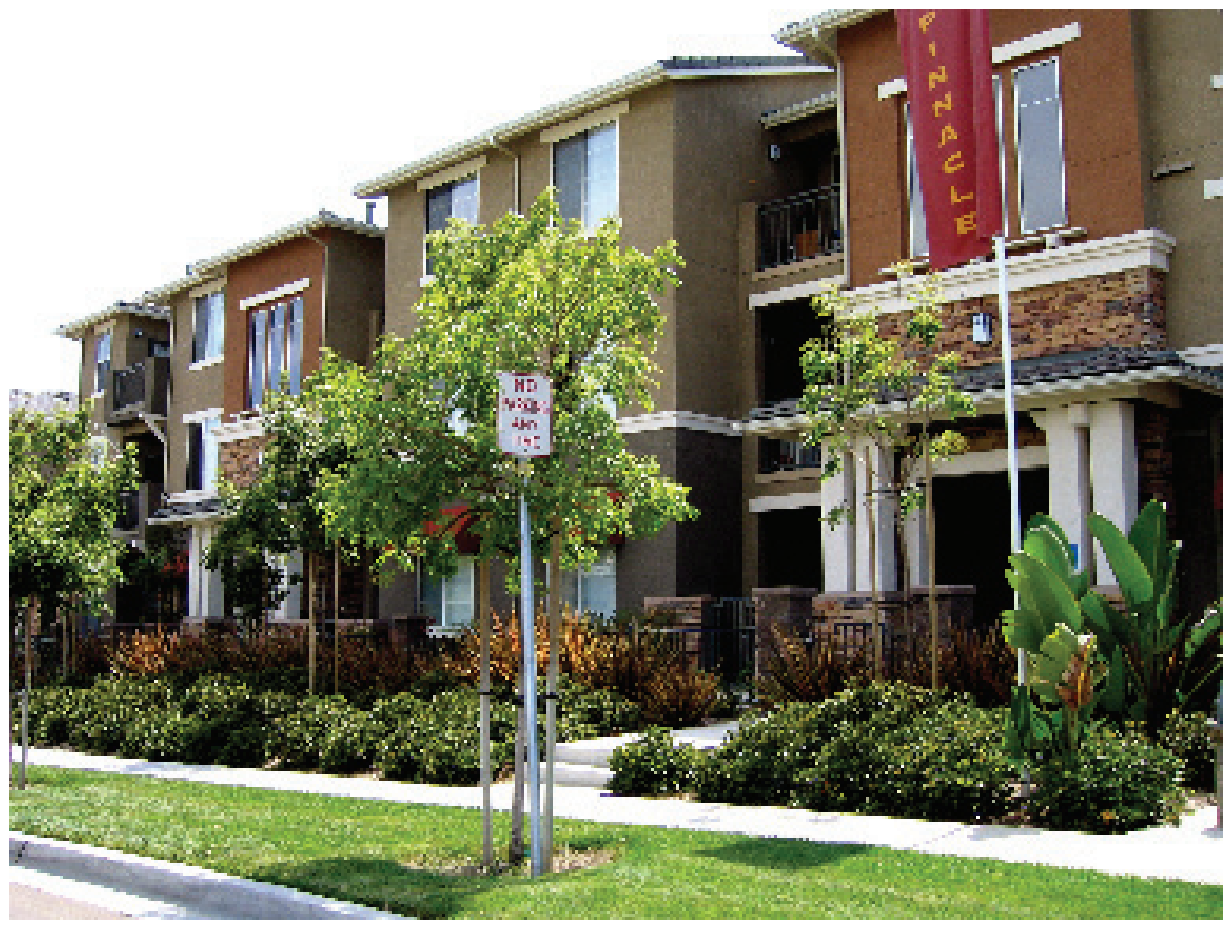


However, it is early yet to make a reliable evaluation of the lasting impact of this movement, and more serious research on the performance of these projects have yet to be done ${ }^{2}$. The critics agree, however, that in spite of its shortcomings, new urbanism is very effective in the restructuring of urban development patterns and curtailing sprawl. It cannot be denied that a model that respects regional context, creates a sense of community, advocates compact development around transit stations, promotes social integration, and calls for development of diverse neighborhoods with a mix of uses, is by far more superior to the current alternative. The characteristics of today's american suburbs and cities in respect to their economic prosperity, physical character and impact on the natural environment, are a good illustration of the shortcomings of the current model shaping the american built environment. New urbanism offers a set of ideas expressed in a charter with no legal power, but these ideas have been influential enough to change professional practice and public policies countrywide, and have certainly carved a market niche.

(2) For example, see Patterson (1997), Weston (2002) and Keith \& del Rio (2003). 


\section{Bibliographical references}

CALTHORPE, Peter; DUANY, Andres. The regional city: Planning for the end of sprawl. Washington DC: Island Press, 2001.

CALTHORPE, Peter. The new american metropolis. New York: Princeton Architectural Press, 1993.

CONGRESS FOR THE NEW URBANISM. Charter of the New Urbanism. Available at www.cnu.org.

DUANY Andres; TALEN, Emily. Transect Planning. Journal of the American Planning Association, vol. 68, n. 3, p. 245-256, 2002.

DUANY, Andres; PLATER-ZYBERK, Elizabeth; SPECK, Jeff. Suburban Nation. New York: North Point Press, 2000.

DUTTON, John. New american urbanism. Milan: Skira Editore, 2000.

GEDDES, Patrick. Cities in evolution. London: Williams \& Norgate, 1915 (1949).

HALL, Peter. Urban Renaissance/New Urbanism. Journal of the American Planing Association, vol. 66, n. 4, p. 359-360, 2000.

HOWARD, Ebenezer. Tomorrow: A peaceful path to real reform. London: Swan Sonnenshein, 1898.

JACOBS, Jane. The death and life of great american cities. New York: Random House, 1961

KEITH, Trevor; DEL RIO, Vicente. New urbanism: Dependência do Automóvel, Senso de Comunidade. Um estudo comparativo de dois conjuntos residenciais na Califórnia. Vitruvius / Arquitextos. http://www.vitruvius.com.br/arquitextos/arq000/ esp201.asp. 2003.

KRIER, Leon. Houses, places, cities. London: AD Editions, 1984.

LECCESE, Michael; McCORMICK, Kathleen (Eds). Charter of new urbanism. New York: McGraw Hill / Congress for the New Urbanism, 1999.

MUMFORD, Luis. The couture of cities. New York: Harcourt Brace Jovanovich, 1938.

MUSCHAMP, Herbert. Can new urbanism find room for the old? New York Times, June 2, A \& E session, p. 27, 1996.

PATTERSON, Patricia. New urbanism and the elderly in urban and suburban development. PhD dissertation. Portland University, Oregon. 1997.

WESTON, Lisa. A methodology to evaluate neighborhood urban form: A comparison of new urbanists principles. Planning Forum, vol. 8, p. 64-78, 2002. 